http://ejurnal.ubharajaya.ac.id/index.php/EDUKARYA

\title{
Penerapan Model Pembelajaran Think Talk Write untuk Meningkatkan Keterampilan Menulis Teks Petunjuk
}

\author{
Khujah Iis Farsyafat ${ }^{1^{*}}$ \\ ${ }^{1}$ SDN 1 Lemahabang, Jl. Ki Hajar Dewantara No. 35 Desa Lemahabang, Kecamatan \\ Lemahabang, Kabupaten Cirebon, Indonesia \\ e-mail: ${ }^{1}$ farsyafatis@gmail.com \\ *Korespondensi e-mail: farsyafatis@gmail.com
}

\begin{abstract}
The background of this study there is difficulties in students in making text instructions about saving energy. The problem caused by learning activity using teacher-centered. To solve the problem are using think talk write model at learning activity. This study aims to improve learning activity and learning outcomes for writing skill text instruction. The method used was action research with a design referring to the spiral model by Kemmis \& Taggart. The study conducted on students of class IV-B SDN 223 Bhakti Winaya, Bandung City. The instruments used were teacher performance observation sheets, student activity sheets, interviews guideline, anecdotal records, and students learning outcomes tests. The results showed an increase in teacher performance planning and student activities from cycle I to cycle II. In addition, the skill of writing instructional texts about saving energy has increased. In the initial data, only 9 students reached KKM, after cycle I as many as 17 students reached KKM and continued to increase in cycle II reaching 28 students who reached KKM. It shows that the use of the think talk write model can improve the writing skills of students in class IV-B SDN 223 Bhakti Winaya.
\end{abstract}

Keywords: Think Talk Write, Writing Skill.

Abstrak
Latar belakang penelitian ini adalah adanya kesulitan siswa dalam membuat teks petunjuk menghemat energi. Masalah tersebut muncul dikarenakan kegiatan pembelajaran yang berfokus pada guru. Tindakan yang dilakukan untuk mengatasi masalah tersebut dengan melakukan pembelajaran menggunakan model think talk write. Tujuan penelitian ini adalah memperbaiki proses dan hasil belajar dalam keterampilan menulis teks petunjuk. Metode penelitian yang digunakan adalah penelitian tindakan kelas dengan desain penelitian mengacu pada model spiral oleh Kemmis \& Taggart. Penelitian dilakukan terhadap siswa kelas IV-B SDN 223 Bhakti Winaya, Kota Bandung. Instrumen yang digunakan adalah lembar observasi kinerja pendidik, lembar observasi aktivitas siswa, pedoman wawancara, catatan lapangan serta tes hasil belajar siswa. Hasil penelitian menunjukkan adanya peningkatan perencanaan kinerja guru dan aktivitas siswa dari siklus I hingga siklus II. Selain itu, keterampilan menulis teks petunjuk menghemat energi menhalami peningkatan. Pada data awal hanya 9 orang siswa yang mencapai KKM, setelah siklus I sebanyak 17 orang siswa mecapai KKM dan terus meningkat pada siklus II mencapai 28 orang siswa yang mencapai KKM. Ini menunjukkan bahwa penggunaan model think talk write dapat meningkatkan keterampilan menulis teks petunjuk siswa kelas IV-B SDN 223 Bhakti Winaya.

Kata kunci: Think Talk Write, Keterampilan Menulis.

\section{PENDAHULUAN}

Merujuk pada kurikulum 2013 bahwa pembelajaran bahasa Indonesia di tingkat sekolah dasar hendaknya menuntut siswa untuk aktif dan kreatif. Ini menuntuk guru untuk lebih kreatif, salah satunya dengan mengambangkan pembelajaran dengan konsep learning by doing. UNESCO (Hamdani, 2011) mengemukakan learning by do merupakan 
konsep belajar untuk menguasasi keterampilan. Keterampilan tersebut sangat berguna dalam membantu siswa sehingga mampu menopang kehidupannya kelak.

Menurut Djuanda (2014) sesuai dengan kurikulum 2013 pembelajaran bahasa Indonesia di sekolah dasar menganut pendekatan komunikatif. Hal tersebut berimplikasi terhadap pembelajaran bahasa Indonesia agar pembelajaran mendorong siswa untuk lebih komunikatif. Sebagaimana diketahui bahwa dalam pembelajaran bahasa Indonesia menekankan pada pengembangan empat keterampilan berbahasa yaitu keterampilan menyimak, berbicara, membaca, dan menulis.

Empat keterampilan berbahasa digolongkan ke dalam dua jenis yakni keterampilan yang bersifat reseftif dan produktif. Keterampilan berbahasa yang bersifat reseftif mencakup keterampilan menyimak dan membaca. Keterampilan tersebut pada dasarnya merupakan keterampilan dalam proses memahami bahasa berbantuan orang lain melalui bunyi maupun tulisan. Singkatnya keterampilan tersebut bersifat menerima informasi dari orang lain. Keterampilan berbahasa yang bersifat produktif yaitu berbicara dan menulis. Keterampilan berbahasa merupakan keterampilan yang menghasilkan sesuatu baik lisan maupun tulisan.

Keterampilan menulis mutlak diperlukan dalam kehidupan sehari-hari. Ini sangat diperlukan untuk menunjukkan seseorang dapat berkomunikasi dengan orang lain melalui tulisan apabila seseorang memahami lambang-lambang grafis yang dimaksud. Suriamiharja (Djuanda, 2008) mengemukakan menulis merupakan kegiatan melahirkan pikiran dan perasaan dengan tulisan. Hal tersebut dapat diartikan bahwa menulis adalah berkomunikasi mengungkapkan pikiran, perasaan, dan kehendak kepada orang lain secara tertulis.

Pembelajaran bahasa Indonesia di SD yang terjadi di lapangan identic dengan pendekatan teacher centered. Studi pendahuluan yang dilakukan berdasarkan hasil observasi dan wawancara mengenai kompetensi dasar matapelajaran bahasa Indonesia menulis teks petunjuk ditemukan beberapa masalah, yaitu: 1) ketika menjawab pertanyaan siswa berebut dan berisik; 2) sebagian siswa saat diberikan tugas mereka kembali bertanya terkait perintah tugasnya; 3) saat disukis banya siswa yang mengobrol dan yang bekerja hanya sebagian anggota kelompok saja; 4) siswa rebut di kelas saat guru tidak memberikan intruksi; dan 5) hasil belajar bahasa Indonesia khususnya yang mencakup keterampilan menulis di bawah KKM.

Akibat dari permasalahan tersebut siswa kurang termotivasi untuk belajar, kurangnya perhatian saat belajar, sehingga mengalami kesulitan dalam memahami materi pelajaran khususnya menulis teks petunjuk dan materi menghemat energi. Berdasarkan identifikasi masalah di atas bahwa permasalahan yang muncul terkait pengaturan pembelajaran yang kurang optimal sehingga pembelajaran tidak kondusif. Ini berkaitan dengan pengelolaan kelas dimana salah satu penyebabnya adalah kurang tepatnya model dan pendekatan pembelajaran yang digunakan. Salah satu alternatif model pembelajaran yang diharapkan dapat mengatasi permasalahan tersebut adalah penggunaan model pembelajaran think talk write.

Hasil penelitian Sumayyah, Mustadi, \& Harun (2019) menunjukkan peningkatan aktivitas siswa dalam keterampilan menulis dengan menggunakan model think talk write. Merujuk pada hasil penelitian tersebut diharapkan dengan penggunaan model pembelajaran think talk write akan mampu meningkatkan aktivitas siswa, sehingga pembelajaran lebih aktif dan komunikatif sebagaimana yang diharapkan sesuai kurikulum 2013. Beberapa penelitian lain juga menunjukkan efektivitas penggunaan model pembelajaran think talk write dalam meingkatkan keterampilan menulis di sekolah dasar. 
Sebagaimana penelitian Arista \& Putra (2019) menunjukkan model pembelajaran think talk write berbasis literasi telah mampu meningkatkan keterampilan menulis siswa sekolah dasar dibandingkan dengan pembelajaran konvesional. Ini didukung dengan penelitian yang dilakukan Arifin, Huda, \& Listyarini (2019) bahwa model pembelajaran think talk write berbantuan gambar seri lebih efektif dalam meningkatkan keterampilan menulis karangan narasi siswa kelas V SD. Berdsarkan hal tersebut diharapkan penggunaan model think talk write juga mampu memperbaiki proses dan hasil belajar siswa SDN 223cBhakti Winaya kelas IV-B sebagai subjek penelitian ini.

Di samping itu, rekomendasi penelitian Fitri \& Atmazaki (2020) penggunaan teknik think talk write disarankan untuk digunakan dalam mengembangkan keterampilan menulis teks petunjuk. Ini sesuai dengan penelitian yang dilakukan bahwa pembelajaran think talk write akan digunakan dalam mengembangkan keterampilan menulis teks petunjuk. Oleh karena itu, penelitian dilakukan dengan tujuan untuk meningkatkan keterampilan menulis teks petunjuk melalui penerapan model pembelajaran think talk write guna memperbaiki proses dan hasil belajar siswa kelas IV-B SDN 223 Bhakti Winaya Kecamatan Regol Kota Bandung.

\section{METODE PENELITIAN}

Metode penelitian yang digunakan adalah penelitian tindakan kelas dengan desain yang mengacu pada model spiral Kemmis \& Taggart. Model ini terdiri dari empat tahapan yaitu perencanaan, pelaksanaan tindakan, pengamatan, dan refleksi sebagaimana lyang tercantum pada Gambar 1. di bawah ini (Wiriaatmadja, 2012, hlm. 66).

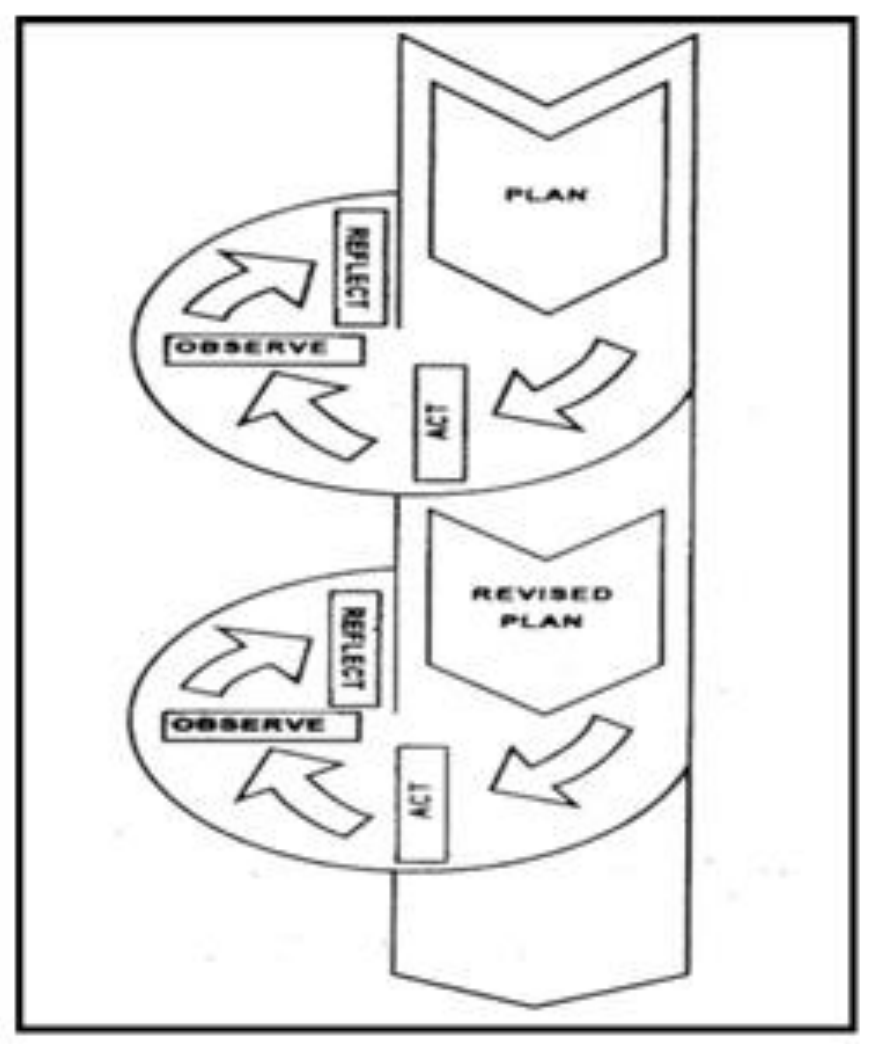

Gambar 1. Desain PTK Model Kemmis \& Taggart 
Penelitian ini dilakukan di SDN 223 Bhakti Winaya Kecamatan Regol Kota Bandung dengan subjek penelitian yaitu kelas IV-B sebanyak 30 orang siswa. Instrumen yang digunakan berupa lembar observasi kinerja guru dan aktivitas siswa, pedoman wawancara, catatan anekdot, dan soal serta format tes hasil belajar mengenai keterampulan menulis teks petunjuk. Adapun prosedur penelitian ini adalah sebagai berikut ini.

1. Tahap merencanakan tindakan. Pada tahap ini dilakukan perancangan RPP data awal, mengobservasi dan wawancara kondisi dan situasi kegiatan pembelajaran di kelas IV-B SDN 223 Bhakti Winaya sebagai data awal. Data awal yang diperoleh diidentifikasi, selanjutnya menentukan tindakan, merancang dan menetapkan instrumen, serta melihat RPP data awal di kelas tersebut.

2. Tahap pelaksanaan. Pada tahap ini dilakukan proses pembelajaran sesui rancangan pembelajaran yang telah disusun dengan menggunakan model think talk write dan terdiri dari beberapa siklus sesuai dengan keberhasilan target yang telah direncanakan.

3. Tahap observasi. Pada tahap ini dilakukan pengamatan terhadap kinerja guru dan aktivitas siswa dalam proses pembelajaran dengan menggunakan model think talk write.

4. Tahap analisis dan refleksi. Pada tahap ini dilakukan analisis dan refleksi terkait rencana dan kegiatan pembelajaran yang telah dilakukan serta data yang diperoleh berdasarkan data awal dan siklus I. Adapun refleksi mencakup mengecek data hasil observasi kinerja guru dan aktivitas siswa, melakukan diskusi dan dilakukan triangulasi, serta menyusun kembali RPP untuk tindakan selanjutnya.

\section{HASIL DAN PEMBAHASAN}

Data awal mengenai proses dan hasil pembelajaran menulis teks petunjuk kelas IVB SDN 223 Bhakti Winaya diperoleh melalui observasi awal dan wawancara dengan guru kelas. Adapun paparan data awal tersebut adalah sebagai berikut ini.

1. Kinerja Guru

Setelah merencanakan pembelajaran, guru melaksanakan kegiatan pembelajaran dengan menggunakan metode ceramah dan diskusi mengenai menulis teks petunjuk menghemat energi. Guru menjelaskan teks petunjuk menghemat energy, kemudian melakukan tanya jawab. Saat bertanya jawab siswa berebut untuk bertanya sehingga kelas menjadi gaduh dan tidak kondusif.

Setelah itu, guru memberikan instruksi agar siswa melakukan pengamatan dengan objek pengamatan lapangan sekolah. Guru membagi siswa ke dalam enam kelompok. Namun, setiap instruksi yang disampaikan guru masih belum dipahami siswa sehingga siswa bertanya kembali terkait perintah dan tugas yang harus dilaksanakannya.

Selama pembelajaran, guru lebih banyak menggunakan metode ceramah, dibandingkan metode diskusi padahal dalam proses pembelajaran menulis teks petunjuk menghemat energi membutuhkan aktivitas kerja kelompok. Selain itu, pengaturan kondisi kelas yang dilakukan guru kurang efektif, ini terlihat drai banyak siswa yang berisik, asik dengan masalahnya sendiri, tidak memahami perintah tugas, dan belum mampu melakukan kerja sama.

2. Aktivitas Siswa

Kondisi aktivitas siswa cenderung aktif. Ketika dihadapkan pada kondisi menjawab atau mengajukan pertanyaan, mereka cenderung menunjukkan sikap berebut untuk 
menjawab pertanyaan sehingga kelas menjadi gaduh dan berisik. Keaktifan siswa dalam pembelajaran menyebabkan kelas menjadi berisik.

Siswa dibagi ke dalam enam kelompok untuk berdiskusi membuat teks petunjuk menghemat energy. Tetapi dalam pelaksanaannya sebagai siswa masih kebingungan dan bertanya kembali terkait perintah yang diberikan guru. Saat diskusi, banyak siswa yang mengobrol dan yang bekerja hanya beberapa orang saja dalam kelompoknya. Ada sekitar delapan orang siswa yang saat proses diskusi mereka berjalan-jalan ke kelompok lain.

3. Hasil Belajar

Hasil belajar siswa dalam keterampilan menulis teks petunjuk menghemat energi dari 30 orang siswa, hanya 9 orang siswa (30\%) yang memenuhi Kriteria Ketuntasan Minimal (KKM). Adapun KKM yang digunakan adalah 70,00. Sementara sisanya sebanyak 21 orang $(70 \%)$ belum memenuhi KKM.

Hasil observasi data awal yang diperoleh kemudian dianalisis dan dilakukan refleksi serta dikonfirmasikan dengan wali kelas IV-B melalui tahap wawancara, akhirnya diperoleh suatu kesimpulan bahwa guru menginginkan sebuah alternatif yang dapat digunakan agar pembelajaran menulis teks petunjuk menghemat energi dapat dikemas menjadi pembelajaran yang menarik. Alternatif tersebut yaitu penerapan model pembelajaran think talk write. Dengan diterapkannya tindakan tersebut diharapkan dapat meningkatkan keterampilan menulis teks petunjuk menghemat energi.

Berdasarkan data awal yang diperoleh, dilakukan tindakan untuk memperbaiki proses dan hasil belajar bahasa Indonesia dalam materi menulis teks petunjuk menghemat energi. Pembelajaran direncanakan dan dilaksanakan dengan menggunakan model pembelajaran think talk write. Sebelum dilakukan tindakan siklus I, dibuat terlebih dahulu perencanaan tindakan sebagai berikut ini.

1) Merumuskan indikator yang sesuai dengan tujuan rencana pelaksanaan pembelajaran yang dirancang menggunakan model pembelajaran think talk write.

2) Mempersiapkan Rencana Pelaksanaan Pembelajaran (RPP) yang dirancang menggunakan model pembelajaran think talk write.

3) Mempersiapkan materi ajar menulis teks petunjuk menghemat energi sesuai tujuan pembelajaran yang telah dirumuskan.

4) Menyusun Lembar Kerja Siswa (LKS), alat evaluasi, dan pedoman penskoran, yang disesuaikan dengan model pembelajaran think talk write dan materi ajar.

5) Mendesain alat evaluasi untuk memperoleh gambaran keterampilan menulis teks petunjuk menghemat energi.

6) Membuat instrumen penelitian pembelajaran menulis teks petunjuk menghemat energi dengan menggunakan model pembelajaran think talk write yang meliputi lembar observasi kinerja guru, observasi aktivitas siswa, catatan anekdot, dan pedoman wawancara.

Pelaksanaan tindakan siklus I sesuai dengan perencanaan yang telah dibuat. Adapun hasil observasi kinerja guru dan aktivitas siswa serta hasil belajar mengenai keterampilan menulis teks petunjuk menghemat energi pada siklus I dapat dilihat pada Tabel 1 di bawah ini. 
Tabel 1. Hasil Analisis Data Siklus 1

\begin{tabular}{|c|c|c|c|}
\hline $\begin{array}{l}\text { Aspek } \\
\text { yang } \\
\text { diamati }\end{array}$ & Fakta yang Ditemukan & Target & Keterangan \\
\hline $\begin{array}{l}\text { Kinerja } \\
\text { Guru }\end{array}$ & $\begin{array}{l}\text { Perencanaan kinerja guru mencapai } \\
92,51 \% \text { dari data awal, dengan } \\
\text { kriteria "Sangat Baik". Sedangkan } \\
\text { pelaksanaan kinerja guru pada } \\
\text { siklus I mengalami peningkatan } \\
\text { mencapai 88,89\% dari data awal, } \\
\text { dengan kriteria Sangat Baik". }\end{array}$ & $\begin{array}{l}\text { Target yang } \\
\text { diharapkan } \\
\text { mencapai } \geq \\
100 \% \text { dari semua } \\
\text { aspek yang } \\
\text { dinilai } \\
\text { memperoleh skor } \\
4 \text { dan mendapat } \\
\text { kriteria "Baik } \\
\text { Sekali." }\end{array}$ & $\begin{array}{l}\text { Target } \\
\text { belum } \\
\text { tercapai } \\
\text { perlu adanya } \\
\text { perbaikan } \\
\text { pada } \\
\text { tindakan } \\
\text { selanjutnya. }\end{array}$ \\
\hline $\begin{array}{l}\text { Aktivitas } \\
\text { Siswa }\end{array}$ & $\begin{array}{l}\text { Data aktivitas siswa saat siklus I } \\
\text { mendapat interprestasi B (baik) } \\
\text { yaitu } 14 \text { orang siswa atau } 53,85 \% \text {. } \\
\text { Sedangkan yang mendapat } \\
\text { interprestasi C (cukup) pada siklus I } \\
\text { berjumlah } 12 \text { peserta didik atau } \\
46,15 \% \text { dan dapat dikatakan semua } \\
\text { peserta didik mendapatkan nilai di } \\
\text { atas nilai K (kurang). }\end{array}$ & $\begin{array}{l}\text { Target yang } \\
\text { diharapkan } \\
\text { mencapai } \geq 85 \% \\
\text { dari jumlah siswa } \\
\text { memperoleh } \\
\text { nilai denga } \\
\text { kriteria Baik } \\
\text { Sekali. }\end{array}$ & $\begin{array}{l}\text { Target } \\
\text { belum } \\
\text { tercapai } \\
\text { perlu adanya } \\
\text { perbaikan } \\
\text { pada } \\
\text { tindakan } \\
\text { selanjutnya. }\end{array}$ \\
\hline $\begin{array}{l}\text { Tes Hasil } \\
\text { Belajar }\end{array}$ & $\begin{array}{l}\text { Dari hasil tes hanya } 17 \text { orang siswa } \\
\text { atau } 56,67 \% \text { yang dinyatakan tuntas } \\
\text { KKM atau } \geq \text { nilai KKM. }\end{array}$ & $\begin{array}{l}\text { Target yang } \\
\text { diharapkan } \\
\text { mencapai } \geq 85 \% \\
\text { dari jumlah siswa } \\
\text { yaitu } 26 \text { orang } \\
\text { siswa yang tuntas } \\
\text { KKM. }\end{array}$ & $\begin{array}{l}\text { Target } \\
\text { belum } \\
\text { tercapai } \\
\text { perlu adanya } \\
\text { perbaikan } \\
\text { pada } \\
\text { tindakan } \\
\text { selanjutnya. }\end{array}$ \\
\hline
\end{tabular}

Berdasarkan hasil analisis data pada siklus I diperoleh kesimpulan bahwa proses dan hasil belajar siswa dalam pembelajaran keterampilan menulis teks petunjuk mengalami peningkatan dibandingkan dengan data awal yang diperoleh. Namun, peningkatan tersebut belum mencapai target dimana hasil belajar siswa yang mencapai KKM hanya 56,67\%, sehingga diperlukan upaya tindakan siklus II. Sebelum dilakukan tindakan siklus II, terlebih dahulu dilakukan perencanaan kembali untuk menyusun pembelajaran yang akan dilakukan pada siklus II. Adpun perencanaan pada siklus II dilakukan sebagai berikut ini.

1. Setelah diputuskan dilakukannya siklus II berdasarkan hasil diskusi dengan guru dan pihal lain dalam penelitian, disusun kembali RPP. RPP pada siklus II ini tidak jauh berbeda dengan siklus I yakni mengembangkan keterampilan menulis menggunakan model think talk write.

2. Mengatur kelas dan tempat duduk terlebih dahulu untuk kegiatan kelompok sebelum pembelajaran dimulai. 
3. Dalam menyampaikan tujuan pembelajaran, guru juga akan menyampaikan langkah-langkah menulis teks petunjuk menghemat energi dengan menggunakna model think talk write.

4. Menjelaskan materi dan melakukan tanya jawab mengenai pengertian dan langkahlangkah menulis teks petunjuk menghemat energi.

5. Membimbing setiap kelompok selama pelaksanaan pembelajaran dengan menggunakan model pembelajaran think talk write.

6. Menyiapkan lembar observasi perencanaan kinerja guru, lembar observasi kinerja guru, lembar observasi aktivitas siswa, dan pedoman penskoran yang digunakan sebagai pedoman pelaksanaan penelitian siklus II.

Pelaksanaan tindakan siklus II dilaksanakan sesuai dengan perencanaan yang telah dibuat. Hasil analisis data pada siklus II diperoleh bahwa perencanaan dan pelaksanaan kinerja guru mencapai $100 \%$ serta aktivitas siswa mencapai 96,67\%. Dimana persentase tersebut telah mencapai target sehingga tidak perlu dilakukan tindakan perbaikan proses pembelajaran lagi. Selain itu, hasil belajar juga mencapai target yakni sebesar 93,33\% yang tuntas KKM. Sisanya terdapat sekitar 6,67\% atau 2 orang siswa yang belum mencapai KKM/belum tuntas. Tindakan lanjutan untuk siswa yang belum tuntas dilakukan remedial.

Hasil observasi kinerja guru dan aktivitas siswa serta hasil belajar mengenai keterampilan menulis teks petunjuk menghemat energi pada siklus II dapat dilihat pada Tabel 2 di bawah ini.

Tabel 2. Hasil Analisis Data Siklus II

\begin{tabular}{|c|c|c|c|}
\hline $\begin{array}{l}\text { Aspek } \\
\text { yang } \\
\text { diamati }\end{array}$ & Fakta yang Ditemukan & Target & Keterangan \\
\hline $\begin{array}{l}\text { Kinerja } \\
\text { Guru }\end{array}$ & $\begin{array}{l}\text { Perencanaan guru pada siklus II } \\
\text { mengalami peningkatan dari tindakan } \\
\text { sebelumnya. Yakni siklus I dengan } \\
\text { persentase } 92,5 \% \text { dan pada siklus II } \\
\text { perencanaan kinerja pendidik sudah } \\
\text { mencapai yang ditergetkan, yaitu } \\
100 \% \text { dengan kriteria Baik Sekali. } \\
\text { Pelaksanaan kinerja guru pada siklus II } \\
\text { mengalami peningkatan dari tindakan } \\
\text { sebelumnya. Yakni siklus I dengan } \\
\text { persentase } 88,89 \% \text { mengalami } \\
\text { peningkatan mencapai persentase } 100 \\
\% \text { dengan kriteria penilaian baik } \\
\text { sekali. Sehingga pada siklus II sudah } \\
\text { mencapai yang ditergetkan yaitu } \\
\text { mencapai nilai } 100 \% \text { dengan kriteria } \\
\text { Baik Sekali. }\end{array}$ & $\begin{array}{l}\text { Target yang } \\
\text { diharapkan } \\
\text { mencapai } \geq \\
100 \% \text { dari } \\
\text { semua } \\
\text { aspek yang } \\
\text { dinilai } \\
\text { memperoleh } \\
\text { skor 4 dan } \\
\text { mendapat } \\
\text { kriteria } \\
\text { penilaian } \\
\text { Baik Sekali. }\end{array}$ & $\begin{array}{l}\text { Target } \\
\text { sudah } \\
\text { tercapai, } \\
\text { tidak perlu } \\
\text { adanya } \\
\text { perbaikan } \\
\text { pada } \\
\text { tindakan } \\
\text { selanjutnya. }\end{array}$ \\
\hline $\begin{array}{l}\text { Aktivitas } \\
\text { Siswa }\end{array}$ & $\begin{array}{l}\text { Data aktivitas siswa pada siklus I } \\
\text { berlangsung, dapat dikatakan bahwa } \\
\text { siswa yang tuntas yaitu } 20 \text { orang siswa }\end{array}$ & $\begin{array}{l}\text { Target yang } \\
\text { diharapkan } \\
\text { mencapai } \geq \\
85 \% \text { dari }\end{array}$ & $\begin{array}{l}\text { Target } \\
\text { sudah } \\
\text { tercapai, } \\
\text { tidak perlu }\end{array}$ \\
\hline
\end{tabular}




\begin{tabular}{|c|c|c|c|}
\hline $\begin{array}{l}\text { Aspek } \\
\text { yang }\end{array}$ & Fakta yang Ditemukan & Target & Keterangan \\
\hline & $\begin{array}{l}\text { atau } 66,67 \% \text { meningkat pada siklus II } \\
\text { menjadi } 29 \text { orang siswa atau } 96,67 \% \text {. }\end{array}$ & $\begin{array}{l}\text { jumlah } \\
\text { siswa } \\
\text { memperoleh } \\
\text { nilai dengan } \\
\text { kriteria } \\
\text { penilaian } \\
\text { baik. }\end{array}$ & $\begin{array}{l}\text { adanya } \\
\text { perbaikan } \\
\text { pada } \\
\text { tindakan } \\
\text { selanjutnya. }\end{array}$ \\
\hline $\begin{array}{l}\text { Tes Hasil } \\
\text { Belajar }\end{array}$ & $\begin{array}{l}\text { Dari hasil tes keterampilan menulis } \\
\text { teks petunjuk menghemat energi } \\
\text { meningkat dari hasil tes siklus I yang } \\
\text { mencapai hanya } 17 \text { orang siswa atau } \\
56,67 \% \text {, pada siklus II meningkat } \\
\text { menjadi } 28 \text { orang siswa atau } 93,33 \% \text {, } \\
\text { yang dinyatakan tuntas KKM atau } \geq \\
\text { nilai KKM }\end{array}$ & $\begin{array}{l}\text { Target yang } \\
\text { diharapkan } \\
\text { mencapai } \geq \\
85 \% \text { dari } \\
\text { jumlah } \\
\text { siswa yaitu } \\
28 \text { orang } \\
\text { siswa } \\
\text { mencapai } \\
\text { KKM. }\end{array}$ & $\begin{array}{l}\text { Target } \\
\text { sudah } \\
\text { tercapai, } \\
\text { tidak perlu } \\
\text { adanya } \\
\text { perbaikan } \\
\text { pada } \\
\text { tindakan } \\
\text { selanjutnya. }\end{array}$ \\
\hline
\end{tabular}

Analisis hasil penelitian didasarkan pada empat aspek mencakup perencanaan kegiatan, kinerja guru, aktivitas siswa, dan hasil belajar siswa mengenai keterampilan menulis teks petunjuk. Keempat aspek tersebut secara garis besar merupakan proses dan hasil belajar. Di awal setiap siklus dilakukan perencanaan kegiatan yang berbeda sesuai dengan hasil temuan di lapangan. Namun, model yang digunakan yakni sama yaitu think talk write dan penggunaan LKS. LKS disusun sesuai dengan langkah-langkah model pembelajaran think talk write yang digunakan. Penggunaan LKS tersebut meudahkan siswa dalam mengikuti proses pembelajaran tahap demi tahap. Ini sejalan dengan pendapat Tarigan, Agung, \& Parmiti (2019) bahwa LKS membantu guru dalam menyampaikan materi dan membantu siswa dalam proses belajar yang disampaikan melalui media LKS. Tahapan-tahapan dalam LKS yang mencakup tahapan think talk write tentunya memudahkan siswa mengikuti tahapan pembelajaran yang telah direncanakan, sehingga tujuan pembelajaran tercapai. Selain itu, LKS juga memberikan motivasi belajar bagi siswa (Sakdiah \& Kurniati, 2019).

Pembuatan perencanaan kegiatan pada siklus I dan dilakukannya perubahan pada siklus II tidak lain bertujuan untuk memperbaiki proses pembelajaran mencakup kinerja guru dan aktivitas siswa. Diharapkan peningkatan perencanaan kegiatan juga menunjang peningkatan kinerja guru dan aktivitas siswa. Adapun peningkatan perencanaan kegiatan dapat dilihat pada Gambar 1 di bawah ini. 


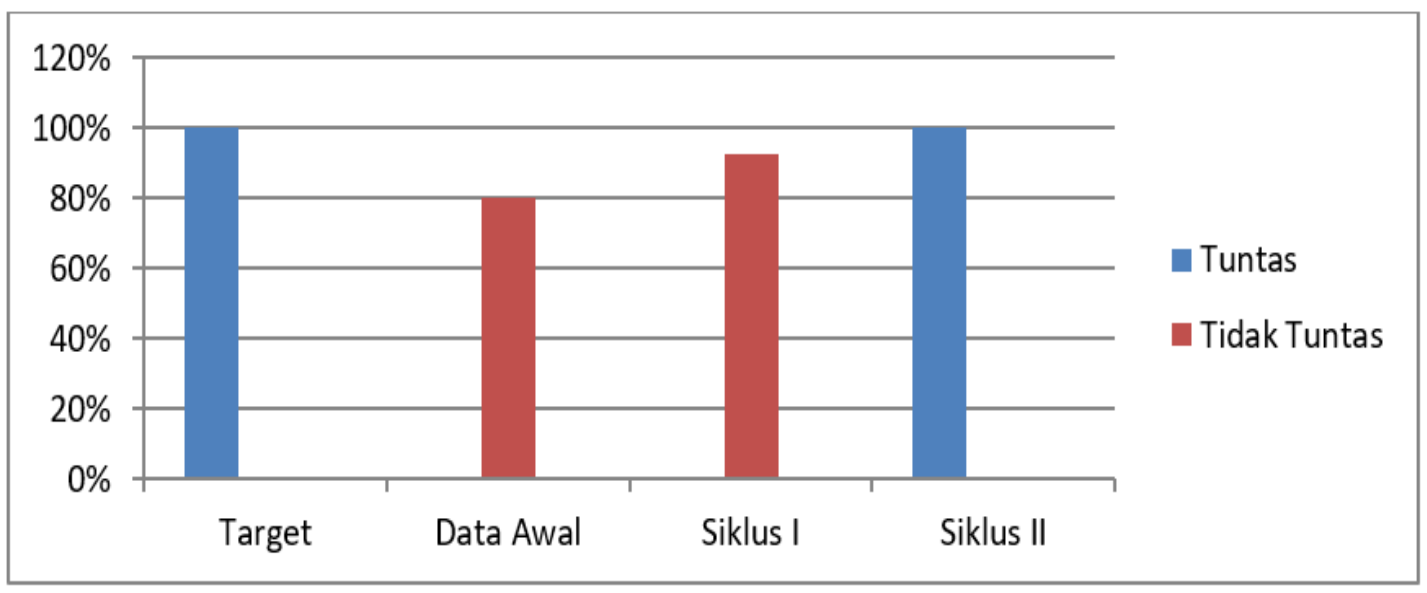

Gambar 1. Peningkatan Perencanaan Kegiatan

Kinerja guru yang dilakukan selama pelaksanaan siklus I dan II juga mengacu pada tahapan model pembelajaran think talk write. Tahapan pertama think, pada tahap ini guru membimbing siswa untuk melakukan pengamatan sebuah poster teks petunjuk menghemat energi. Tahapan kedua talk, pada tahap ini guru membimbing siswa untuk melakukan diksusi kelompok dengan membandingkan kedua teks petunjuk menghemat energi dengan menuliskan persamaan dan perbedaan kedua teks tersebut. Tahapan ketiga write, dimana pada tahap ini guru memberikan kesempatan dan membimbing siswa untuk menulis teks petunjuk secara bekelompok. Dilihat berdasarkan tahapannya, bahwa pembelajaran tidak lagi bersifat teacher centered dimana tugas guru yang tercermin dalam setiap tahapan pembelajaran adalah memfasilitasi dan membimbing bukan sekedar transfer pengetahuan. Ini tentunya memberikan perubahan pembelajaran yang tadinya pada data awal teacher centered menjadi student centered. Kondisi pembelajaran student centered menjadikan siswa lebih aktif dalam pembelajaran (Suhariami, Hariani, \& Firdaus, 2019). Ini mendorong terciptanya pembelajaran yang aktif dan komunikatif sebagaimana yang diharapkan kurikulum 2013. Penggunaan model pembelajaran think talk write tersebut berimplikasi terhadap peningkatan kinerja guru dalam menulis teks petunjuk menghemat energi.

Tahapan-tahapan dalam model think talk write yang mendorong siswa aktif belajar dimana melibatkan siswa dalam proses kerja sama kelompok di setiap tahapannya. Dalam pembelajaran ini siswa belajar melalui diskusi kelompok dari mulai mengamati teks petunjuk menghemat energi pada tahap think, menganalisi dan membandingkan dua teks petunjuk menghemat energi pada tahap talk sampai membuat teks petunjuk menghemat energi pada tahap write, siswa dapat bekerja sama sesuai dengan tugas yang diberikan dalam proses pembelajaran. Ini menunjukkan dengan model pembelajaran think talk write dapat meningkatkan aktivitas siswa karena dengan melakukan langkah demi langkah pembeljaaran siswa akan langsung mengalaminya, sehingga siswa aktif dan mencari tau untuk menyimpulkan apa yang mereka pahami dan alami. Ini sejalan dengan teori kontruktivisme yang dipelopori Piaget, Bruner, dan Vygotsky bahwa pengetahuan dan pemahaman tidak diperoleh secara pasif melainkan dengan cara atif melalui pengalaman personal dan aktivitas eksperimental (Anggara, Santosa, \& Udayana, 2019). Jelas bahwa dalam pembelajaran yang menggunakan model think talk write mendorong siswa untuk beraktivitas berdasarkan pengalaman dan eksperimen melibatkan daya pikir, indra, dan 
tindakan sehingga aktivitas siswa yang diamati pun meningkat dari data awal yang diperoleh, siklus I, dan siklus II.

Pada pelaksanaan kegiatan pembelajaran siklus I diperoleh data bahwa dari 30 orang siswa yang mendapat kriteria B (Baik) ada 20 peserta didik $(66,67 \%)$, pada dan pada siklus II target sudah tercapai $100 \%$ melebihi dari yang telah ditargetkan yaitu $85 \%$. Peningkatan aktivitas siswa pada sisklus I, dan II dapat digambarkan dalam Gambar 2 di bawah ini.

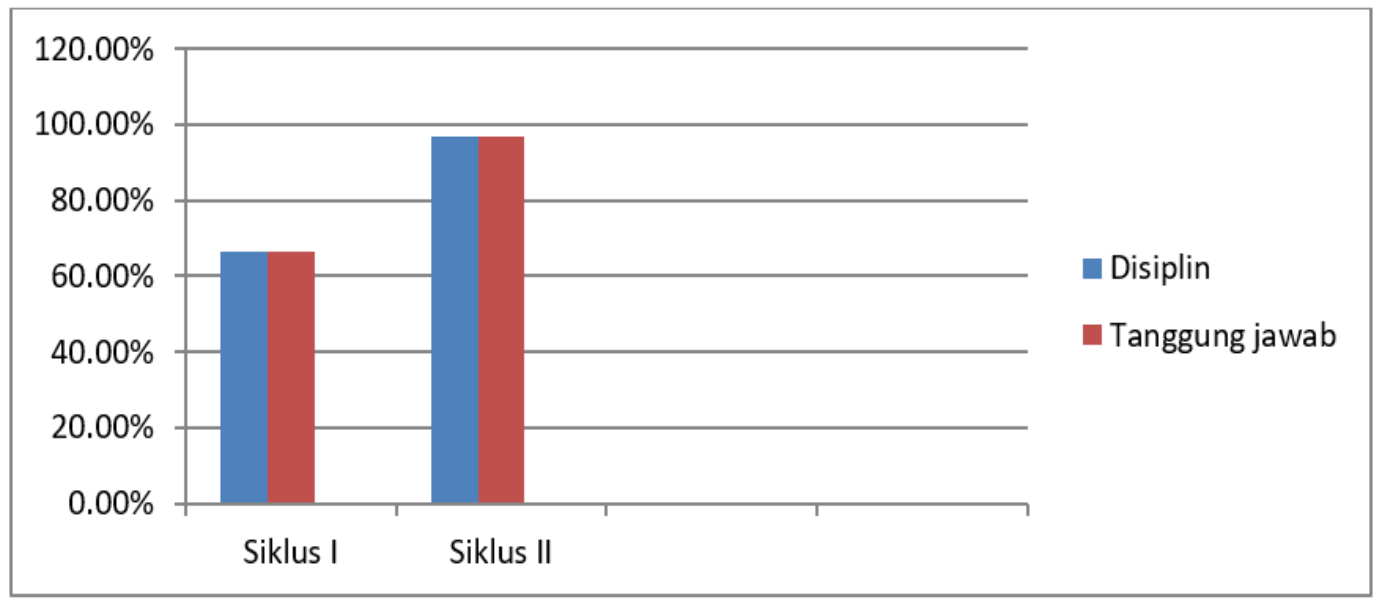

Gambar 2. Peningkatan Aktivitas Siswa

Hasil belajar siswa dalam keterampilan menulis teks petunjuk menghemat energy mengalami peningkatan dari data awal, siklus I, dan siklus II. Dari tes awal terlihat hasil menulis teks petunjuk menghemat energi dari 30 orang siswa hanya 9 peserta didik yang tuntas artinya $30 \%$ siswa memenuhi KKM menulis teks petunjuk menghemat energi sedangkan sisanya 21 orang siswa belum tuntas artinya $70 \%$ belum dapat memenuhi KKM.

Berdasarkan pemaparan hasil tes belajar siswa pada siklus I dapat disimpulkan dalam tes hasil belajar siswa dari jumlah 30 siswa hanya 17 orang siswa atau $(56,67 \%)$ dapat memenuhi KKM menulis teks petunjuk menghemat energy. Sementara sisanya 13 orang siswa atau $(43,33 \%)$ belum memenuhi KKM. Pada siklus II dapat disimpulkan hasil belajar siswa dari jumlah 30 orang siswa hanya 28 orang siswa atau $(93,33 \%)$ dapat memenuhi KKM, artinya target sudah tercapai $100 \%$ melebihi dari yang telah ditargetkan yaitu sebesar $85 \%$. Peningkatan tersebut tentunya merupakan implikasi dari penggunaan model pembelajaran think talk write. Ini sejalan dengan penelitian tindakan kelas yang telah dilakukan Aryananda, Chamisijatin, \& Hafi (2019); Dery, Pebriana, \& Putra (2019) bahwa penggunaan model think talk write telah meningkatkan proses dan hasil belajar siswa SD dalam keterampilan menulis. Hal tersebut jelas menunjukkan bahwa model pembelajaran think talk write sebagai alternatif solusi dalam meningkatkan proses dan hasil belajar bahasa Indonesia di SD, utamanya dalam meningkatkan keterampilan menulis khususnya menulis teks petunjuk.

\section{SIMPULAN DAN REKOMENDASI}

Penggunaan model pembelajaran think talk write memberikan peningkatan terhadap proses dan hasil belajar bahasa Indonesia dalam keterampilan menulis teks petunjuk. Perencanaan kegiatan, kinerja guru, aktivitas siswa, dan hasil belajar pun meningkat berdasarkan data awal, siklus I, dan siklus II. Kinerja guru di siklus I telah 
dicapai dengan baik mencapai $88,89 \%$ dengan kriteria baik sekali dan pada siklus II mencapai $100 \%$ mengalami peningkatan dengan kriteria baik sekali. Aktivitas siswa pada siklus I mencapai $66,67 \%$ dan siklus II mencapai $96,67 \%$. Peningkatan pada aktivitas siswa dari siklus I sampai siklus II pada umumnya menyangkut semua aspek penilaian, yakni disiplin dan kerjasama. Hasil belajar keterampilan menulis teks petunjuk menghemat energi dari setiap siklus mengalami peningkatan. Mulai data awal siswa yang tuntas mencapai KKM 30\%, pada siklus I meningkat menjadi 56,67\%, dan pada siklus II yang tuntas mencapai KKM meningkat menjadi 93,33\%. Target sudah melebihi dari yang telah ditargetkan yaitu sebesar 85\%. Diharapkan hasil penelitian ini menjadi pertimbangan bagi guru untuk menggunakan model pembelajaran think talk write dalam memperbaiki proses dan hasil belajar bahasa Indonesia khususnya keterampilan menulis. Selain itu, hasil temuan dalam penelitian ini diharapkan dapat menjadi bahan referensi peneliti lain mengembangkan model pembelajaran think talk write.

\section{DAFTAR PUSTAKA}

Anggara, I.G.A.S., Santosa, H., \& Udayana, A.A.G.B. (2019). Character education and moral value in 2d animation film entitled pendeta bangau. CAPTURE: Jurnal Seni Media Rekam, 10 (2), 57 - 70.

Arifin, A.Z., Huda, C., \& Listyarini, I. (2019). Kefektifan model think talk write berbantu media gambar seri terhadap keterampilan menulis. International of Elemetary Education, 3 (3), 301 - 307.

Arista, N.L.P.Y. \& Putra, D.K.S. (2019). Pengaruh model pembelajaran think talk write (ttw) berbasis literasi terhadap keterampilan menulis dalam bahasa Indonesia. International Journal of Elementary Education, 3 (3), 284 - 292.

Aryananda, J, Chamisijatin, L, \& Hafi, A. (2019). Penerapan model think talk write untuk meningkatkan keterampilan menulis kalimat efektif pada siswa kelas III sdn Sumbersari 1 kota Malang. Jurnal Basicedu, 3 (1), 118 - 124.

Dery, D.W., Pebriana, P.H. \& Putra, K.E. (2019). Penerapan model kooperatif tipe think talk write untuk meningkatkan keterampilan menulis karangan narasi pada siswa sekolah dasar. Jurnal Pendidikan dan Konseling, 1 (1), 1 - 11.

Djuanda, D. (2008). Pembelajaran keterampilan berbahasa Indonesia di sekolah dasar. Bandung: Pustaka Latifah.

Djuanda, D. (2014). Pembelajaran bahasa indonesia yang komunikatif dan menyenangkan. Sumedang: UPI Sumedang PRESS.

Fitri, J. \& Atmazaki. (2020). Pengaruh penggunaan teknik think talk write (ttw) berbantuan media gambar berseri terhadap keterampilan menulis teks prosedur siswa kelas vii smp negeri 11 Padang. Jurnal Pendidikan Bahasa dan Sastra Indonesia, 9 (1), 103 - 111.

Hamdani. (2011). Strategi belajar mengajar. Bandung: Pustaka Setia Bandung.

Sakdiah, S. \& Kurniati, K. (2019). Analisis pemanfaatan lks terhadap motivasi belajar siswa pada mata pelajaran ekonomi kelas XI di sman 4 Mataram. SOCIETY, 10 (1), $18-37$.

Suhariami, Y., Hariani, L.S., \& Firdaus, R.M. (2019). Berpikir kritis: students centered learning (scl) dan reciprocal teaching. Jurnal Riset Pendidikan Ekonomi, 4 (1), 1 -8 .

Sumayyah, Mustadi, A. \& Harun. (2019). Penilaian aktivitas siswa dalam keterampilan menulis melalui model think talk write. Premiere Educandum: Jurnal Pendidikan Dasar dan Pembelajaran, 9 (1), 23 - 33. 
Tarigan, B.N.B., Agung, A.A.G., \& Parmiti, D.P. (2019). Pengembangan lembar kerja siswa (lks) bermuatan karakter untuk meningkatkan hasil belajar ipa. Journal of Education Technology, 3 (3), 179 - 185.

Wiriaatmadja. R. (2012). Metode penelitian tindakan kelas. Bandung: PT Remaja Rosdakarya. 